Grievance Redress by Courts in Consumer Finance Disputes

No. 331

18-March-2021

Karan Gulati and Renuka Sane

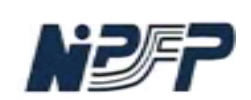

National Institute of Public Finance and Policy New Delhi 


\title{
Grievance Redress by Courts in Consumer Finance Disputes
}

\author{
Karan Gulati Renuka Sane*
}

March 18, 2021

\begin{abstract}
This paper studies how courts in India have dealt with consumer finance disputes. It presents the organisation of the courts that hear consumer finance cases. It reviews the 60 most cited cases to study the position that courts have taken in banking and insurance disputes. For the cases studied, it finds that courts have generally granted relief to consumers in banking disputes. In the case of insurance, courts have emphasised contractual compliance. This is so even if the contracts themselves were opaque or had unfair terms. The paper also finds that courts award low compensation and take a long time for adjudication. It suggests that courts should put in place systems to facilitate class action suits and bring in specialisation to deal with consumer finance disputes.
\end{abstract}

${ }^{*}$ The authors are researchers at NIPFP. We thank Vimal Balasubramaniam, Sudipto Banerjee, Adam Feibelman, K. P. Krishnan, Smriti Parsheera, and Srishti Sharma for their comments. We are also thankful to participants at the webinar series on grievance redress organised by NIPFP, and Emerging Markets Conference, 2020. Author names are in alphabetical order. 


\section{Contents}

1 Introduction $\quad 3$

2 Financial sector regulation in India $\quad 5$

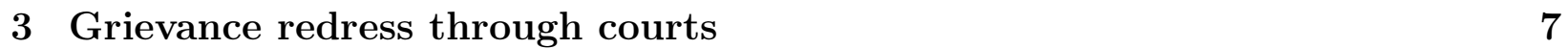

3.1 A consumer finance complaint . . . . . . . . . . . . . . . . . . . . . 7

3.2 Consumer protection courts . . . . . . . . . . . . . . . . 8

3.3 Constitutional courts . . . . . . . . . . . . . . . . . . 11

3.4 Alternate dispute resolution . . . . . . . . . . . . . . . . . . . . . 12

3.5 What can the courts do? . . . . . . . . . . . . . . . . 13

4 What have the courts done? 15

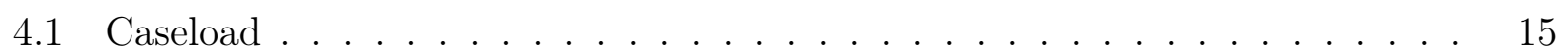

4.2 Banking . . . . . . . . . . . . . . . . . . . . 18

4.3 Insurance . . . . . . . . . . . . . . . . . . . . . . . 20

4.4 Caveat emptor . . . . . . . . . . . . . . . . . . . . . . . 22

5 Challenges in court functioning $\quad 24$

5.1 Low compensation . . . . . . . . . . . . . . . . . 24

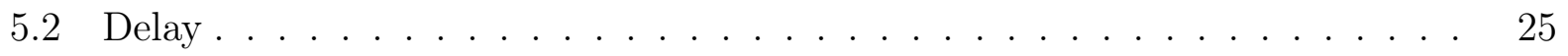

5.3 No class action . . . . . . . . . . . . . . . . . 27

5.4 Specialisation . . . . . . . . . . . . . . . . . . 28

$6 \quad$ Way forward $\quad 29$

7 Conclusion $\quad 33$ 


\section{Introduction}

Consumer finance is an important sector in any economy. It channels household savings to productive uses while providing tools for consumption smoothing and risk management. As with any sector, consumer finance sees its share of disputes between service providers and consumers. Disputes range from transaction-related grievances such as money getting stuck in an ATM $^{1}$ to mis-selling of products ${ }^{2}$ to fraud. ${ }^{3}$ The complexity of financial markets and the existence of market failures such as information asymmetry, and unequal bargaining power, create the need for a higher standard of protection for financial consumers. This is especially because, unlike physical products, grievances concerning financial products can directly impact the economy due to an erosion of consumer trust.

In 2019, India enacted a new Consumer Protection Act (CPA) to protect consumer interests and provide timely and effective settlement of disputes. ${ }^{4}$ The objective of such specialised laws is to protect consumers against wrongs committed by providers of goods and services, for which the remedy under ordinary laws has become illusory. The Act entrusts courts to redress grievances and protect consumers. Moreover, due to the poor track record of Indian financial regulators, courts are often the only available recourse for retail consumers. ${ }^{5}$ Hence, understanding the role that courts play in consumer finance becomes important for two reasons. First, it can provide information on the nature of disputes and be a valuable tool for regulators to tighten existing consumer protection provisions. The precedent can also help companies avoid disputes in the first place. Second, it can provide information to

\footnotetext{
${ }^{1}$ Anecdotes of cheques getting delayed, bank lockers being misused, people being harassed for repayment are also common.

${ }^{2}$ For example, Halan, Sane, and Thomas (2014) show that investors lost up to US $\$ 28$ billion to mis-selling of unit-linked insurance products between 2005 and 2012. Monika Halan, Renuka Sane, and Susan Thomas, "The case of the missing billions: estimating losses to customers due to mis-sold life insurance policies" (2014) 17(4) Journal of Economic Policy Reform 285. Similarly, Anagol and Kim (2012) estimate losses of US $\$ 350$ million from shrouding of fees by Indian mutual funds. Santosh Anagol and Hugh Hoikwang Kim, "The impact of shrouded fees: Evidence from a natural experiment in the Indian mutual funds market" (2012) 102(1) American Economic Review 576.

${ }^{3}$ For example, Moneylife (2020) reports that there were 84,545 frauds involving ₹ 1,85,772 crore reported by banks and select financial institutions in FY 2019-20. Moneylife, About 84,545 bank fraud cases reported during 2019-20: RBI in RTI reply (27 July 2020) /https://www.moneycontrol.com/news/india/about84545-bank-fraud-cases-reported-during-2019-20-rbi-in-rti-reply-5605441.html $\rangle$.

${ }^{4}$ Consumer Protection Act 2019. This replaced the erstwhile Act of 1986.

${ }^{5}$ Borate (2020) documents "regulator apathy" and denial of redress to mis-sold retail investors by financial regulators. Neil Borate, Those mis-sold Yes Bank AT1 bonds face long haul (Livemint 11 May 2020) 〈https: / / www . livemint. com / money / personal - finance / those - mis- sold - yes - bank - at1 - bonds - face- long- haul11589216126345.html $\rangle$.
} 
new tech platforms that help the transition towards "Online Dispute Resolution (ODR)" in consumer finance. ${ }^{6}$

Despite the existence of specialised consumer courts since 1986, the literature on what role courts have played in consumer finance redress issues in India is relatively scant. Our paper aims to fill this gap. It describes the structure of the courts that consumers can access consumer courts established under the CPA, High Courts, and the Supreme Court of India. These courts are parallel to the grievance redress mechanisms run by the financial sector regulators. Consumers can approach either the courts or the regulators. The paper focuses on complaints made in writing by a "retail" consumer - that is someone who buys goods or avails services for consideration or is a beneficiary of a contract of service. ${ }^{7}$

To evaluate the decisions that courts have taken on banking and insurance cases, we study the 60 most cited cases. ${ }^{8}$ These include 40 judgments by consumer commissions and 20 by constitutional courts (High Courts of various States and the Supreme Court of India). ${ }^{9}$ Courts have generally granted relief to consumers in banking disputes, but only when the complaint was filed without delay. In insurance disputes, courts have emphasised contractual compliance. This meant that consumers did not get a remedy when the contracts had unfair term, or when consumers did not understand the terms.

In 2013, the Financial Sector Legislative Reforms Commission (FSLRC) recommended that consumer protection legislation demand Financial Service Providers (FSPs) to write contracts that consumers can understand. However, the government has not yet followed through on these recommendations. ${ }^{10}$ In 2018, a bill was introduced in the Indian parliament

\footnotetext{
${ }^{6}$ NITI Aayog, Agami, and Omidyar Network India, Catalyzing Online Dispute Resolution in India (2020) $\langle$ https://niti.gov.in/catalyzing-online-dispute-resolution-india\#p2 $\rangle$.

${ }^{7}$ The paper does not study debt recovery mechanisms by creditors (often banks) or proceedings initiated by industry regulators such as the Insurance Regulatory and Development Authority (IRDA). These are not complaints initiated by a retail consumer.

${ }^{8}$ This includes references across commercial databases (SCC Online and Manupatra), (ii) books on consumer protection (see for example, Rajyalakshmi Rao, Consumer is King (vol 4, Universal Law Publishing 2015) and Avtar Singh, Consumer Protection Law and Practice (vol 5, Eastern Book Company 2015)), and (iii) leading online daily prints (such as Hindustan Times and the Times of India).

${ }^{9}$ India follows a strict form of stare decisis i.e. courts are obligated to follow historical cases of equal or higher courts (such as the Supreme Court of India) when pronouncing judgment in a similar subsequent dispute.

${ }^{10}$ Financial Sector Legislative Reforms Commission, "Report of the financial sector legislative reforms commission, Vol I, New Delhi" [2013]. It also recommended that an unfair term should be void. This included terms that caused an imbalance in the rights and obligations of the parties but were not necessary to protect their interests.
} 
to ensure that parties understand contract terms; however, it did not pass the floor. ${ }^{11}$ In the absence of such a law, courts only repudiate contracts when consumers do not know the terms instead of understanding them. These issues are compounded by the shortcomings in the framework of courts - they tend to award low compensation, take a long time for adjudication, do not have systems for class action suits, and lack specialisation to deal with consumer finance issues.

As India makes progress on financial inclusion through greater use of digital payments and fintech, an increasing number of people, especially from the lower socio-income strata, are beginning to interact with the consumer finance industry. This will invariably lead to greater frictions and an increasing number of grievances. Unless these are satisfactorily resolved, we may end up with further erosion of trust, ultimately hurting the progress made on financial inclusion. Effective consumer protection is required to promote financial stability. While India needs to set up good regulator-based grievance redress mechanisms such as a Financial Redress Agency, it also needs to improve the functioning of courts to provide effective relief in consumer finance (and other) disputes.

The rest of this paper is organised as follows: section 2 describes the choice between courts and regulators in India. Section 3 deals with how consumer finance disputes move through the courts. To those familiar with the court system, we would suggest moving on to section 4 , which discusses court decisions on banking and insurance. Section 5 highlights some of the challenges that have arisen through this process, and section 6 provides recommendations on how to address them. Finally, section 7 concludes the paper.

\section{Financial sector regulation in India}

Before studying courts, it is important to understand the landscape of financial sector regulation in India. The first market regulator in India, the Reserve Bank of India (RBI), was established in 1934. ${ }^{12}$ Since then, India established three more regulators, viz. the IRDA, the Pension Fund Regulatory and Development Authority (PFRDA), and the Securities and Exchange Board of India (SEBI). These were a consequence of India's liberalisation journey between 1991 and 2002. ${ }^{13}$ They were intended to regulate the burst of activities in the concerned sectors. Each regulator aims to enhance "consumer protection" and has set up its

\footnotetext{
${ }^{11}$ Unfair (Procedural and Substantive) Terms of Contracts Bill 2018.

${ }^{12}$ Reserve Bank of India Act 1934.

${ }^{13}$ Ila Patnaik and Ajay Shah, "Reforming India's Financial System" [2014] Carnegie Endowment for International Peace.
} 
own grievance redress mechanism. Typically, consumer finance disputes would be resolved through grievance redress mechanisms set up by the regulators. Examples include the Australian Financial Complaints Authority (AFCA) in Australia, Financial Ombudsman Service (FOS) in the United Kingdom, and the Consumer Financial Protection Bureau (CFPB) complaints mechanism in the United States. When such a mechanism works, consumers seem to prefer it over courts. ${ }^{14}$

However, the regulatory complaints system in India is fragmented. ${ }^{15}$ For example, while an ombudsman addresses banking and insurance grievances, the securities market is based on a self-enforcement mechanism. On the other hand, claims related to pensions are processed by a Central Record-keeping Agency and an Ombudsman. Complainants have to decipher the regulator to approach in case of a grievance (see fig. 1). Moreover, high vacancy and the lack of efficient enforcement mechanisms disincentivise consumers from approaching regulators in the first place. ${ }^{16}$ For instance, there was no regular insurance ombudsman in Ahmadabad between July 2014 and October 2018 - more than four years. ${ }^{17}$ This was probably at the forefront in 2017, when officials at ombudsman offices reportedly advised policyholders to instead approach consumer courts. ${ }^{18}$ Even when regulators hear disputes, they reject the claims as non-maintainable or without merit and pass an award in as little as 100 complaints per year. ${ }^{19}$ In such an environment, courts become an important forum for grievance redress in consumer finance. Unless inefficiencies at regulators are addressed to attract confidence; consumers will continue to prefer courts for grievance redress.

\footnotetext{
${ }^{14}$ For example, Schwarcz (2009) highlights the efficiency gains by approaching the FOS, operating parallel to courts, in the United Kingdom. Daniel Schwarcz, "Redesigning consumer dispute resolution: A case study of the British and American approaches to insurance claims conflict" (2008) 83 Tul L Rev 735. Similarly, Howell (2019) shows that in Australia, most matters involving consumer credit law are resolved through AFCA and not litigated through courts. Nicola Howell, "Shutting the courts out: Developing consumer credit law in the shadow of alternative dispute resolution and the new Australian Financial Complaints Authority" (2019) 30(2) Journal of Banking and Finance Law and Practice 57.

${ }^{15}$ Government of India, "Report of the Task Force on Financial Redress Agency" [2016].

${ }^{16}$ Shefali Malhotra, Ila Patnaik, and others, "Fair play in Indian health insurance" [2018] NIPFP Working Paper No 228.

${ }^{17}$ Executive Council of Insurers, "Annual Report 2018 - 2019" [2019].

${ }^{18}$ Rachel Chitra, 16 vacant ombudsman offices hit policyholders (The Times of India 16 December 2017) 〈https : / / timesofindia . indiatimes . com / business / india - business / 16 - vacant - ombudsman - offices - hit policyholders/articleshow/62091638.cms .

${ }^{19}$ In 2018-19, the Banking Ombudsman passed 98 awards. Reserve Bank of India, The Reserve Bank of India Ombudsman Schemes: Annual Report 2018-19 (2019). See also, Sucheta Dalal, Banking Ombudsman is not working (Moneylife 18 February 2014) 〈https://www.moneylife.in/article/banking-ombudsman-isnot-working/36391.html $\rangle$.
} 


\section{Grievance redress through courts}

India enacted its consumer protection law in 1986 in the form of the Consumer Protection Act. It provided three levels of grievance redress bodies: (i) District, (ii) State, and (iii) National commissions. Though the Act was substituted in 2019 by an eponymous law, the grievance redress structure has largely remained the same. ${ }^{20}$ The commissions deal with all consumer disputes and are not restricted to consumer finance cases. They have, however, developed considerable jurisprudence since they came into force. Aside from these commissions, India's consumer protection cases may also be decided by the High Courts of various States and the Supreme Court of India. All these forums have varying levels of power in granting relief to aggrieved parties.

\subsection{A consumer finance complaint}

Grievances concerning consumer finance may refer to several possibilities. They may arise out of complaints by consumers, regulators, banks, creditors, etc. However, we restrict ourselves to complaints made by consumers. This refers to allegations in writings by those who consume the goods or services. It is thus important to define what is meant by 'complaint' and 'consumer' in our study.

Complaint: Consumers of finance can be of many types - customers of banking, insurance, capital markets - and a complainant means that they are aggrieved by the goods or services provided. However, every aggrieved consumer is not a complainant. This requires one to file a complaint i.e. an allegation made in writing for the redress of grievances. These grievances can include both price terms (such as rate of interest) or non-price terms (such as harsh collection terms).

Consumer: A complaint must be made by a consumer. As per the CPA, a consumer is one who buys goods or avails services for consideration or is a beneficiary of a contract of service. ${ }^{21}$ This does not include a person who buys goods or avails services for any

\footnotetext{
${ }^{20}$ The salient changes include establishing the Central Consumer Protection Authority (CCPA) and the inclusion of e-commerce entities within the Act. Consumers may now approach the new regulator in addition to courts. It can investigate complaints and penalise violations of consumer rights. It may also forward the complaint to a court. However, we have no experience in its performance and interaction with other grievance redress bodies.

${ }^{21}$ Canara Bank v United India Insurance Co 2020 SCC Online SC 132. See also, Lucknow Development Authority v MK Gupta (1994) 1 SCC 243 and Joint Labor Commissioner and Registering Office v Kesar Lal 2020 SCC Online SC 327.
} 
commercial purpose. This restriction is not limited to the courts. Even the banking and insurance regulators prescribe that a complainant ${ }^{22}$ means an individual acting in her personal capacity, ${ }^{23}$ who's claim does not exceed two and three million rupees, respectively. ${ }^{24}$ Thus, an investor who takes a loan for commercial purposes would not be included within the meaning of a consumer and could not file a consumer complaint. ${ }^{25}$ However, providing overdraft facilities for non-commercial use would be a service provided to a consumer. ${ }^{26}$

Thus, it is beyond this paper's scope to delve deeper into debt recovery mechanisms by creditors (often banks) or proceedings initiated by industry regulators such as the IRDA. These proceedings, though relevant, are not complaints initiated by a consumer. ${ }^{27}$

\subsection{Consumer protection courts}

The CPA establishes three levels of courts to address grievances. These are the District Consumer Disputes Redressal Commission (District Commission), the State Consumer Disputes Redressal Commission (State Commission), and the National Consumer Disputes Redressal Commission (National Commission). All three of them have original jurisdiction depending on the monetary claim. This means that a consumer can approach either commission depending on the value of the claim she makes. If no monetary claim is made, the dispute is first heard by the District Commission. Moreover, the State Commission and the National Commission also have appellate jurisdictions. This means that if the decision of the lower commission dissatisfies a consumer, she may appeal to the concerned appellate commission.

If the claim does not exceed ₹ 10,000,000 (US $\$ 138,500$ ), it lies before the District Commission. If the consumer is unhappy with the District Commission's decision, she can appeal to the State Commission on payment of the prescribed fee. ${ }^{28}$ If the claim ranges from

${ }^{22}$ The regulators refer to 'complainants' instead of 'consumers'.

${ }^{23}$ The Insurance Ombudsman $v$ Indus Motor Co P Ltd 2005 SCC OnLine Ker 428.

${ }^{24}$ Banking Ombudsman Scheme 2006, s 12(5); and Insurance Ombudsman Rules 2017, s 17(3)

${ }^{25}$ HDFC Bank Ltd v Subodh Ghanshyam Prabhu II (2014) CPJ 336 (NC). Similarly, when private companies take loans for commercial purposes, they cannot be considered consumers. They cannot file consumer complaints. Zest Infrastructure Private Ltd $v$ HDFC Bank Ltd Civil Appeal No 8509 of 2010.

${ }^{26}$ Vimal Chandra Grover v Bank of India (2000) 5 SCC 122.

${ }^{27}$ For a note on the functioning of such alternate forums, see Sumant Batra, "Insolvency laws in South Asia: Recent trends and developments" [2007] Legal \& Institutional Reforms of Asian Insolvency Systems, OECD 75 .

${ }^{28}$ The fee depends upon the level of the commission and the amount of the claim. It can range from nil before the District Commission for a person below the poverty line to ₹ 7,500 (US \$100) before the National 
₹ $10,000,000$ to ₹ $100,000,000$ (US $\$ 1,385,500$ ), the complaint can be filed directly before the State Commission. As mentioned, the State Commission also hears appeals from the District Commission. It can pass appropriate orders when the District Commission has exercised jurisdiction that is not vested in it. Similarly, the National Commission entertains original complaints above ₹ $100,000,000$ (US $\$ 1,385,500$ ) and appeals from the State Commission. Consumers aggrieved by the order of the National Commission may approach the Supreme Court of India in certain circumstances. However, the jurisdiction of ordinary District Courts and High Courts of various states has explicitly been excluded under the $\mathrm{CPA}^{29}$

Interestingly, these remedies are in addition to any other law in force. The Act only gives consumers additional remedies besides those available under other laws. Thus, though ordinary courts such as District and High Courts cannot be moved under the CPA, they may be approached under other laws. For example, a complaint against a bank may be made directly to the High Court's commercial branch. The Act does not bar remedies under other laws. ${ }^{30}$

Commission.

${ }^{29}$ Nivedita Sharma $v$ Cellular Operators Assn of India (2011) 14 SCC 337.

${ }^{30}$ CCI Chamber Co-operative Housing Society Ltd v Development Credit Bank Ltd (2003) 7 SCC 233. 


\section{Figure 1 The structure of Grievance Redress in India}

The complainant may approach either a consumer court or a separate forum. Within the consumer courts, the path from the District Commission to the Supreme Court depends on the amount of claim and appellate jurisdictions.

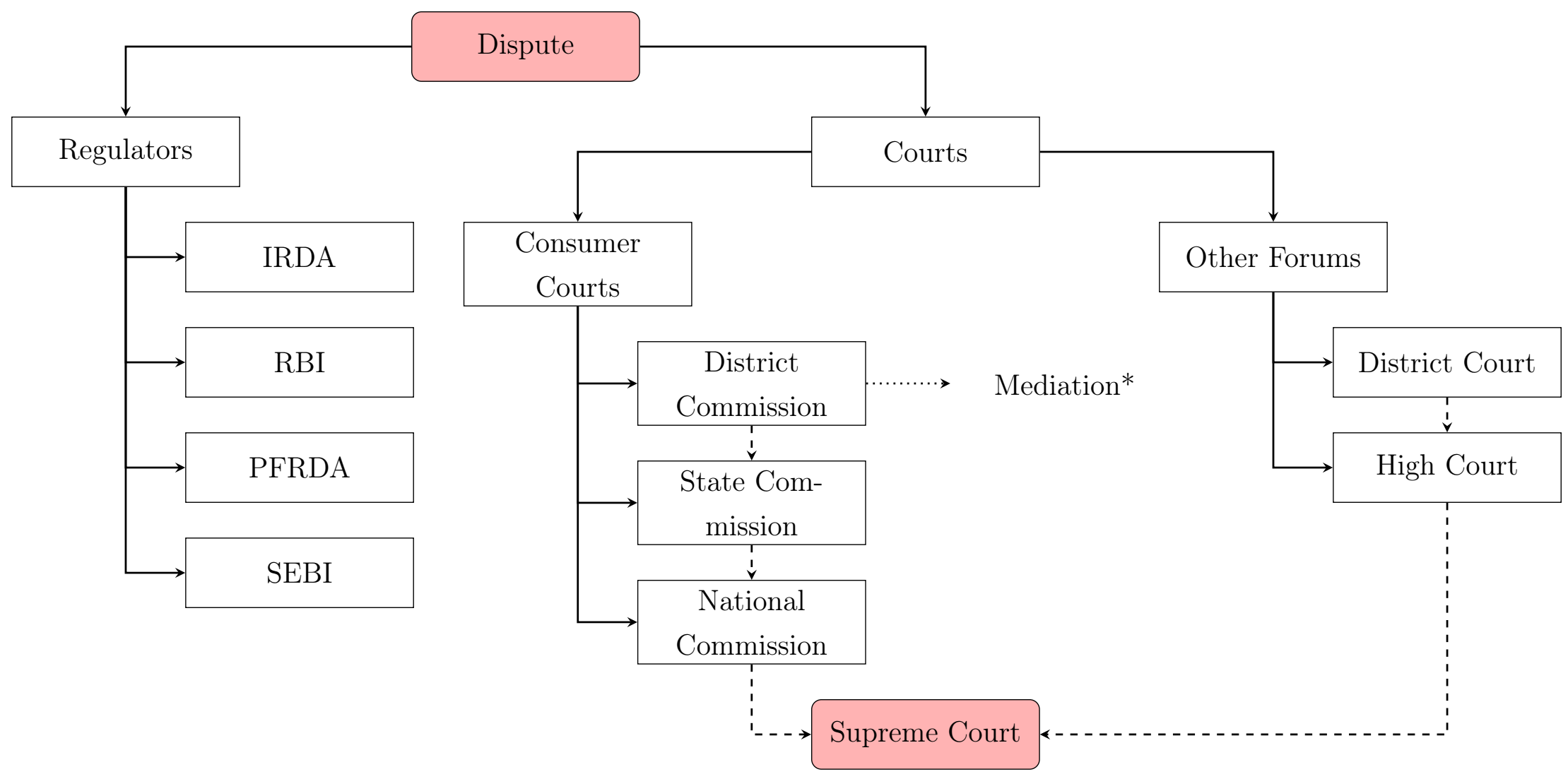

* A commission may send the case to mediation upon its own satisfaction that the dispute is capable of settlement.

— represents and a claim under original jurisdiction; and

- - represents and a claim under appellate jurisdiction 


\subsection{Constitutional courts}

The Constitution of India creates two forms of courts - the High Courts of various States and the Supreme Court of India. These are referred to as Constitutional Courts. ${ }^{31}$ They have varying forms of jurisdiction under the constitution, as well as several other laws. For example, a High Court may be an appellate forum for a lower court (district courts, Zilla Parishads, etc.), have original jurisdiction for writs challenging the violation of a legal right, or initiate suo-moto proceedings. ${ }^{32}$ However, High Courts do not form a part of the flow of a dispute through consumer courts. Thus, if a complainant initiates a proceeding before either commission, a High Court will never adjudicate the case. Of course, this does not mean that consumer finance cases can never come before by a High Court.

As fig. 1 shows, consumers may choose to have their dispute adjudicated outside the CPA. One way of doing so is by approaching a District Court. Here, High Courts serve as the appellate court. Hence, if a consumer is dissatisfied by a District Court, she may appeal to the concerned High Court. An aggrieved party may also approach the High Court directly. Article 226 of the constitution empowers High Courts to issue writs and enforce legal rights. Some High Courts also have original jurisdiction in addition to their power to issue writs. However, this is not a uniform system. ${ }^{33}$ Thus, a finance dispute may reach a High Court in one of three ways, depending on where the court is located - (i) in an appeal from a lower court, (ii) directly under article 226 for the issuance of a writ, and (iii) directly under the original jurisdiction of the court.

Similarly, the Supreme Court has both appellate and original jurisdictions. Unlike High Courts, the Supreme Court's writ jurisdiction is restricted to the violation of fundamental rights. Thus, a complainant may directly approach the court if some fundamental right has been violated. Moreover, under the CPA, the Supreme Court can hear appeals against decisions of the National Commission. However, this is limited to when the National Commission decided the case under its original jurisdiction. Where the commission decides a case in an appeal from the State Commission, no appeal lies before the Supreme Court. This is not to say that the court cannot hear the case in the latter situation. A complainant can still approach the Supreme Court under what is perhaps its most used jurisdiction i.e. a special

\footnotetext{
${ }^{31}$ Though the Constitution mentions subordinate or district courts, it does not establish them. Instead, they are established by Statutes i.e. the Criminal and Civil Procedure Codes.

${ }^{32}$ These are proceedings that the court decides on its own motion. This means that the court took notice of the grievances itself without anyone approaching it.

${ }^{33}$ The High Courts at Delhi, Bombay, Calcutta, and Madras are the only High Courts with original jurisdiction in addition to the power of issuing writs.
} 
leave to appeal under article 136 of the constitution. ${ }^{34}$

Article 136 allows the court to grant a special leave to appeal from any decision by any lower court. However, the appellate proceedings under 136 are not vested rights of the parties. They commence under the discretion of the court. Thus, the Supreme Court may choose to accept the appeal. This is a sweeping power exercisable outside the scope of ordinary laws. The court may hear an appeal even when the legislature declares the lower court or tribunal's decision to be final. Once the special leave has been granted, the case is converted into an appeal.

This has resulted in dual channels for the settlement of finance disputes. The complainant may approach specialised courts i.e. consumer commissions or an ordinary civil court. In both cases, the dispute may be appealed till the Supreme Court. There may be several reasons to choose one forum over the other. Prime among them is the specialisation and efficiency of the court. For example, though a High Court may have more experience dealing with disputes, it does not specialise in consumer cases. Of course, another way of settling disputes is through alternate mechanisms outside courts. These can offer both specialisation and efficiency since parties can choose specialised adjudicators - limited to deciding a specific dispute.

\subsection{Alternate dispute resolution}

Alternate Dispute Resolution (ADR) allows parties to privately resolve their grievances and gives them more autonomy. It acts as a method outside the conventional judicial system where outcomes are more predictable due to the forum's specialisation and efficiency. The Supreme Court has endorsed the benefits of ADR at several instances, observing that "it has a social purpose to fulfil" and "has a great urgency". ${ }^{35}$ This explains why arbitration is widely used across a fora of civil disputes in India. Parties have greater flexibility than court proceedings and are likely to get a speedier remedy. This is important in consumer finance cases, where time is of the essence. Thus, the position regarding ADR in consumer finance

\footnotetext{
${ }^{34}$ Nick Robinson, "A Quantitative Analysis of the Indian Supreme Court's Workload" (2013) 10(3) Journal of Empirical Legal Studies 570; Marguerite J Fisher, "The Supreme Court of India and Judicial Review" (1957) 9 Syracuse L Rev 30; Madhav Khosla, "Addressing judicial activism in the Indian Supreme Court: Towards an evolved debate" (2009) 32 Hastings Int'l \& Comp L Rev 55; Aparna Chandra, William HJ Hubbard, and Sital Kalantry, "The Supreme Court of India: A People's Court?" (2017) 1(2) Indian Law Review 145; and Rahul Hemrajani and Himanshu Agarwal, "A temporal analysis of the Supreme Court of India's workload" (2019) 3(2) Indian Law Review 125.

${ }^{35}$ Food Corporation of India v Joginder Pal Mohinder Pal (1989) 2 SCC 347.
} 
disputes should be clear.

Unfortunately, this has not been the case. This is due to several reasons, prime among them being the varying judgments on the 'nature' of consumer disputes. These have been held to be both 'public' and 'private' in nature. A public nature dispute involves a right exercisable against the world at large (a right in rem). This contrasts with a private dispute, which includes a right exercisable solely against specific individuals (a right in personam). Since public actions determine the parties' rights not only among themselves but against all persons, they are non-arbitrable. On the other hand, private actions only determine the parties' rights and may be subject to arbitration.

In 2010, it appeared that the situation might get some clarification. In $M / s$ Afcons Infra Ltd $v \mathrm{M} / \mathrm{s}$ Cherian Varkey Construction Company $L t d,{ }^{36}$ while enumerating disputes suitable for ADR, the Supreme Court held that all consumer disputes could be referred to ADR. This would have meant that consumer disputes, like other civil disputes, could be referred to arbitration or mediation. However, restrictions soon emerged. In a 2016 judgment, Justice Dr DY Chandrachud held that specific categories of disputes could not be arbitrated if the jurisdiction of those disputes had been granted to a special forum. ${ }^{37}$ Since the legislature has granted jurisdiction in consumer disputes to specialised commissions, they cannot be resolved by arbitration. This reasoning would come to be followed by the court at several instances, including a 2018 judgment in M/s Emaar MGF Land Ltd v Aftab Singh. ${ }^{38}$

Thus, consumer disputes may be settled by an alternate mechanism to courts; however, not by arbitration. Since ADR includes both arbitration and mediation, this means that they may be mediated. This is apparent considering the new CPA of 2019, which states that if a consumer commission believes that the dispute can be settled, it may refer it to mediation. ${ }^{39}$ However, this depends on the subjective satisfaction of the commission. This brings in personal discretion, and no guidelines have been framed on how it should be exercised.

\subsection{What can the courts do?}

The ability of consumers to approach different forums is futile if courts cannot grant appropriate relief. The ability of the court to grant such relief is crucial in achieving the goals of civil litigation. When this is done, parties are deterred from injuring each other. This is

\footnotetext{
${ }^{36} \mathrm{M} / \mathrm{s}$ Afcons Infra Ltd $v \mathrm{M} / \mathrm{s}$ Cherian Varkey Construction Company Ltd (2010) 8 SCC 24.

${ }^{37}$ A Ayyasamy $v$ A Paramasivam (2016) 10 SCC 386.

${ }^{38} \mathrm{M} / \mathrm{s}$ Emaar MGF Land Ltd $v$ Aftab Singh 2018 SCC OnLine SC 2945.

${ }^{39}$ Consumer Protection Act 2019, s 37. See also, Consumer Protection (Mediation) Rules 2020.
} 
because the costs of doing so outweigh the benefits. Similarly, adequate relief also provides insurance to injured parties when deterrence fails.

The powers of courts to grant relief depends on which court the complainant approaches. This is to be expected. The powers of the Supreme Court of India, the highest court in the country, would be broader than the District Commission. Consumer commissions are bound by the powers conferred upon them by the CPA. High Courts are bound to decide cases either within the confines of a statute or the constitution. Going one step further, the Supreme Court has held itself not restricted in any way to grant adequate relief. On the other hand, in mediation, the relief can be anything that the parties agree to among themselves.

Under the CPA, once a complaint is made, a preliminary hearing is given to the complainant. If the commission is satisfied that the complaint is genuine, it issues a notice to the person against whom the complaint is filed. After hearing both the parties, if a deficiency in goods or services is proved, the commission may order appropriate relief. It may order the opposite party to: (i) remove the defect, (ii) return the price of the goods or the charges for the services along with interest, (iii) pay compensation or punitive damages, and (iv) withdraw the goods or services from the market. In one example, an insurance company's refusal to pay the claim to the nominee and request a succession certificate in the absence of rival claims was held to be wrong. The insurer was ordered to satisfy the claim, along with interest at 12\%. ${ }^{40}$ Similarly, where an inordinate delay occurred in settlement of an insurance claim, the complainants were entitled to compensation for physical and mental harassment. ${ }^{41}$

On the other hand, High Courts may or may not be bound by a statute. This depends on how the dispute has come before it. The relief will depend on the statute under which the court hears an appeal, if any, and the provisions of the constitution in cases of writs. Moreover, when statutory powers granted to the court are inadequate, it may fall back on its supervisory powers under the constitution and issue orders that it deems fit. ${ }^{42}$ The court may quash a lower court's decision, issue directions, grant compensation, or remand the case back for re-hearing. It may also pass interim orders to be followed during the pendency of the dispute.

Like High Courts, the Supreme Court's powers to grant relief are hardly restricted. Though

\footnotetext{
${ }^{40}$ Prem Lata Bangad v National Insurance Co I (1991) CPJ 423 (RC).

${ }^{41}$ Padamsri Tobacco Company v National Insurance Co II (2002) CPJ 96 (NC).

${ }^{42}$ See Mani Nariman Daruwala v Phiroz N Bhatena (1991) 3 SCC 141; and Chandravarkar SRR v Ashalata $S$ Guram (1986) 4 SCC 447.
} 
in an appeal from the National Commission, the court should only grant relief as prescribed by the CPA, there can be no statutory restriction on the powers of the court. It may pass orders that it deems necessary or adequate. ${ }^{43}$ Thus, in addition to granting any of the reliefs which may be provided by the Commissions or High Courts, the Supreme Court may pass any other order it deems proper. It has the power to mould relief according to the circumstances of the case. Under article 142 of the constitution, the Supreme Court is entitled to pass any order necessary for doing complete justice in a dispute before it.

\section{What have the courts done?}

The caseload of the courts has varied drastically since the establishment of consumer commissions. To understand how courts treat finance disputes, we rely on data regarding the caseload of the commissions. We source data about the caseload from Confo-net, ${ }^{44}$ the case management system of the National Commission. This included data on the institution and disposal of cases at the National Commission between 1989 and 2019. For parameters related to the courts' application of the law, this is supplemented with manual reading of judgments pronounced during this period. To understand how courts decide cases, we study the 60 most cited cases - 40 judgments by consumer commissions and 20 by constitutional courts (High Courts of various States and the Supreme Court of India).. This includes references across commercial databases (SCC Online and Manupatra), (ii) books on consumer protection (see for example, Rao (2015) and Singh (2015)), ${ }^{45}$ and (iii) leading online daily prints (such as Hindustan Times and the Times of India). This was done to understand the judicial approach while dealing with finance cases. In India, courts are obligated to follow historical cases of equal or higher courts (such as the Supreme Court of India) when pronouncing judgment in a similar subsequent dispute. Though these may highlight consumer experiences, they are not the entire universe of cases heard by courts.

\subsection{Caseload}

Between 1989 and 2019, 207,876 unique cases were instituted before the National Commission. However, these cases were not necessarily to be decided on merit. They included caveat

\footnotetext{
${ }^{43}$ Supreme Court Bar Association v Union of India (1998) 4 SCC 409.

${ }^{44}$ National Informatics Centre, "Computerization and Computer Networking of Consumer Forum in the Country" 〈http://cms.nic.in/ncdrcusersWeb/login.do?method=caseStatus $\rangle$.

${ }^{45}$ Rajyalakshmi Rao, Consumer is King (vol 4, Universal Law Publishing 2015); and Avtar Singh, Consumer Protection Law and Practice (vol 5, Eastern Book Company 2015).
} 
cases, execution, interlocutory, miscellaneous, and transfer applications. ${ }^{46}$ Of these 91,999 cases were initiated for actual adjudication. We sourced cases concerning Banking and Insurance from this universe of cases. This gave us 16,288 cases between 1991 (the first year when a banking or insurance case was initiated) and 2019. Table 1 presents the summary statistics for the data.

Table 1 Summary Statistics

Since 2015, approximately 1400 cases have been initiated each year, but only 335 cases have been decided.

\begin{tabular}{|c|c|c|c|c|c|c|}
\hline & \multicolumn{2}{|c|}{ Banking } & \multicolumn{2}{|c|}{ Insurance } & \multicolumn{2}{|c|}{ Total } \\
\hline & Initiated & Decided & Initiated & Decided & Initiated & Decided \\
\hline Total & 5147 & & 14819 & & 19966 & \\
\hline To be decided on merit & 4005 & & 12283 & & 16288 & \\
\hline $1990-1994$ & 0 & & 3 & & 3 & \\
\hline $1995-1999$ & 59 & & 233 & & 292 & \\
\hline $2000-2004$ & 170 & & 556 & & 726 & \\
\hline $2005-2009$ & 1011 & & 3392 & & 4403 & \\
\hline $2010-2014$ & 1061 & 738 & 2918 & 2055 & 3979 & 2793 \\
\hline $2015-2019$ & 1704 & 412 & 5181 & 1262 & 6885 & 1674 \\
\hline Parties in Person & $482(12 \%)$ & & $628(5 \%)$ & & $1110(7 \%)$ & \\
\hline
\end{tabular}

Source: Confo-Net

The rate of initiation of cases has been on the rise. Most of the cases (over $42 \%$ of those in the 28 years of our data) were initiated between 2014 and 2019. This is reflected in fig. 2. In this period, the National Commission witnessed an $11.61 \%$ compounded annual growth

\footnotetext{
${ }^{46}$ In caveat cases, a party applies to be informed if the opposite party initiates any proceedings; Execution applications are filed for the execution of any orders or directions already passed by the commission; Interlocutory and Miscellaneous applications are filed during a proceeding for permission to file additional documents, condone delay, bring on additional parties, etc.; and Transfer Applications make a case for transferring a dispute from one State Commission to another, or from a District Commission in one State to that in another.
} 
rate in banking and insurance cases. Regardless of the reasons for the increasing cases ${ }^{47}$ it appears that courts are unable to manage the caseload. To understand the growing caseload, we also need to understand - (i) the time taken to decide cases, and (ii) the number of cases decided per year. Unfortunately, Confo-net only provides this information for cases that were decided after 2008. ${ }^{48}$ Hence, our data for the time to decide cases is restricted to 2008-19. ${ }^{49}$ In this period, we looked at 5343 cases (1374 banking cases and 3969 insurance cases). On average, it took 1.99 (median $=0.77$ ) years for banking cases to be decided by the National Commission. For insurance cases, the average is 2.38 (median $=0.98$ ) years. ${ }^{50}$ The commission took over 5 years to decide more than $1 / 5$ th of the cases. Though this may be high, the time taken is less than that by ordinary courts in India.

Figure 2 Number of cases initiated before the National Commission

Over $42 \%$ of all banking and insurance cases have been initiated in the last five years. This represents the increase in the use of consumer courts to settle finance cases.

\section{Cases Initiated before the the NCDRC}

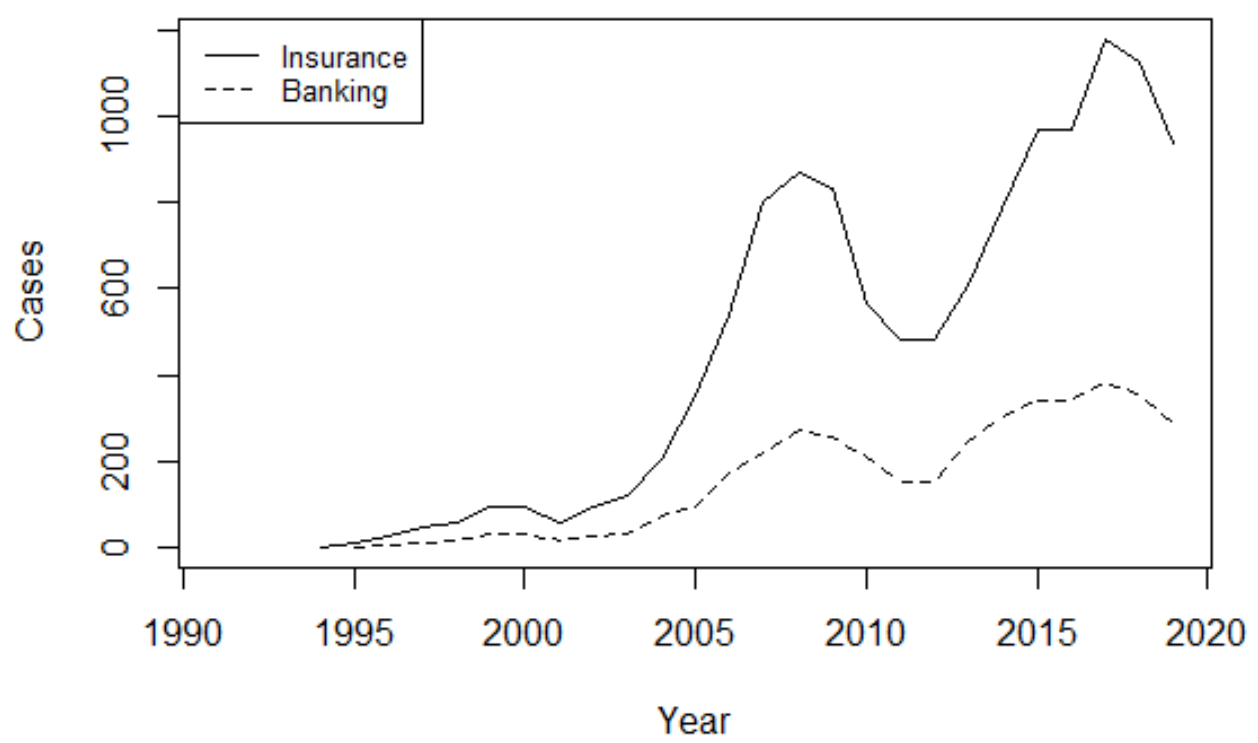

Source: Confo-Net

\footnotetext{
${ }^{47}$ The reasons may range from increased financial access to a growing trust in consumer courts.

${ }^{48}$ This does not mean that these cases were initiated during this period. Cases decided as far back as 1991 will be included in our data if the judgment was pronounced after 2008 .

${ }^{49}$ Due to issues in the quality of data, it does not include cases from 2015.

${ }^{50}$ If a case initiated and disposed before 2008 took lesser time, these numbers might overestimate the delay before the National Commission.
} 
Two years in deciding cases at this stage reflects the delay before the commission. This time does not present a true picture of the cases before the National Commission. Since 2015, approximately 1400 cases were initiated each year, but only 335 cases were decided. These are not small numbers. Their experience shows that even though consumer forums adjudicate cases quicker than ordinary courts, they are still playing catch-up with the initiation rate. This leads to a rising backlog of cases, which will only slow adjudication time in the future.

Lastly, we also observed who comes to the commission to argue cases. This is because if parties have unequal resources, it will likely impact the litigation. Interestingly, parties decided not to engage lawyers in only $7 \%$ of the cases. This meant that they were represented by a person aware of litigation's nuances in all other cases. Though this seems low, it may not represent disputes in consumer courts. Our data only includes cases before the National Commission, the highest consumer forum in the country. Parties may be more prone to appear in person at district and state levels. ${ }^{51}$

\subsection{Banking}

Litigation is disproportionately costly and troublesome for small consumers. Very rarely can an ordinary consumer go through the prolonged ordeal of fighting with a bank. For this reason, courts have granted relief to individual consumers, given that they come with clean hands. ${ }^{52}$ In particular, there are four types of cases where the courts have taken this approach.

1. Banks do not comply with the RBI's circulars or guidelines: Courts generally grant relief when banks behave contrary to circulars or directions issued by the RBI. For example, when the bank refused to pay interest on the complainant's deposit and only returned the principal amount, the commission granted the interest along with compensation. The conduct, it held, was against a circular of the RBI requiring banks to inform depositors about any policy that would restrict or deny interest. ${ }^{53}$ In another example of a similar kind, interest on the encashment of Deep Discount Bonds was supposed to be paid from 1993 to 2008. However, it was only paid till 2002. The

\footnotetext{
${ }^{51}$ Kinhal and Ranjan (2020) found that parties decided not to engage lawyers in $12.2 \%$ of district commission cases in Karnataka. Deepika Kinhal and Aditya Ranjan, Caveat Venditor: An evaluation of Consumer Dispute Redressal Commissions in Karnataka (Vidhi Centre for Legal Policy 2020).

${ }^{52}$ A Brijlal v Oriental Insurance Co I (2007) CPJ 81 (NC), and New India Assurance Co v HS Poultry Farm IV (2011) CPJ 497 (NC).

${ }^{53}$ Vaidyanath Urban Co-op Bank Ltd v Narayan II (2015) CPJ 335 (NC).
} 
commission directed the bank to pay interest from 2002 to 2008 along with costs. ${ }^{54}$ The National Commission also held a bank liable after perusing the RBI procedure for bank lockers. In this case, the bank had not maintained a locker register, locker key register, and not followed the procedure for breaking open a locker. ${ }^{55}$ Likewise, where in accordance with RBI guidelines, instant credit was not given to the consumer for an outstation cheque, resulting in the cheque's dishonour, the bank was held liable. ${ }^{56}$

2. In the absence of guidelines: The National Commission has also taken it upon itself to lay down the procedure when it has not been specified. In Atul Nanda v Reserve Bank of India, the complainant alleged that the bank's policy regarding the period for giving credit was not known to consumers, especially in the case of outstation cheques. The commission directed that (i) local cheques should be credited and debited on the same day or at the most the next day, (ii) the maximum period for collection of outstation cheques should be 14 days, and (iii) a copy of the complete policy should be made available if consumers require. Notably, the commission only obligated the banks to share the policy if the consumer required and did not impose any proactive obligation..$^{57}$

3. Price disputes: Courts have also held banks liable in price disputes such as wrongful withdrawals, ${ }^{58}$ and incorrect outstanding amounts. For instance, an outstanding amount was shown against one Anand Prasad's account. He made a one-time settlement in mid-December 2002. Despite having paid the settlement amount, he kept receiving statements showing the outstanding till June 2003. The bank admitted that it had received the amount, but the department generating the statement of account remained unaware. The commission held that one department of the bank did not know what the other was doing. The consumer could not be harassed this way, and the bank was held liable for deficiency in service. ${ }^{59}$

4. Non-price disputes: Lastly, courts and commissions have continued this trend in non-

${ }^{54}$ Small Industries Development Bank of India (SIDBI) v Dr Saraswati Gupta I (2010) CPJ 460 (UT-Chd).

${ }_{55}^{55}$ Mahender Singh Siwach v Punjab and Sind Bank IV (2006) CPJ 231 (NC).

${ }^{56}$ State Bank of Mysore v TL Vasudeva Rao II (1995) CPJ 231 (SP).

${ }^{57}$ Atul Nanda v Reserve Bank of India III (2008) CPJ 244 (NC).

${ }^{58}$ In Vijaya Bank $v$ Gurnam Singh, the bank allowed withdrawal of ₹ 3,50,000 as overdraft against a cheque leaf reported as lost. It was directed to reimburse this money with costs. Vijaya Bank $v$ Gurnam Singh (2010) 13 SCC 775. See also, Bhadra N Dalal v Bank of India IV (2011) CPJ 330 (NC).

${ }^{59}$ Anand Prasad $v$ Standard Chartered Bank IV (2007) CPJ 159 (NC). 
price disputes such as harsh collection procedures.$^{60}$ In fact, in ICICI Bank v Prakash Kaur, the debtor committed suicide due to harassment by agents of the bank. ${ }^{61}$ In this case, the court suggested that banks be held liable for acts of recovery agents and that the RBI issue qualifications for appointing such agents. Commenting on harsh procedures, the court observed: "we are governed by the rule of law...banks cannot employ goondas to take possession by force". ${ }^{62}$

However, courts also buck the trend of granting relief to consumers. In Vivek Mohan (Dr) $v$ Canara Bank, the complainant's locker was mistakenly broken open by the bank due to a false presumption of arrears. The complainant alleged that the locker contained jewellery and cash valuing ₹ 753,000. Both the District Commission and the State Commission dismissed the complaint simply because of a delay in filing the complaint. ${ }^{63}$ Similarly, in MI Plywood Industries v Canara Bank, the bank failed to hand over the mortgaged property's original documents and the NOC against a loan. The State Commission and National Commission dismissed the case due to a delay of 140 days. This was the case even when the delay had allegedly been caused by the lawyer, and the complainant was old and incapable of moving. ${ }^{64}$

\subsection{Insurance}

Though courts have granted relief to consumers in banking disputes, this has not been the case while interpreting insurance contracts. As early as 1966, the court held that while interpreting a contract of insurance, it must give effect to the meaning and intent that emerges from the terms. In a Constitutional Bench decision, ${ }^{65}$ the Supreme Court observed that:

In interpreting documents relating to a contract of insurance, the duty of the court is to interpret the words in which the contract is expressed by the parties, because it is not for the court to make a new contract, however reasonable, if the parties have not made it themselves... ${ }^{66}$

\footnotetext{
${ }^{60}$ Citicorp Maruti Finance Ltd v S Vijayalakshmi (2012) 1 SCC 1; and Standard Chartered Bank v Vipin Kumar Gupta II (2006) CPJ 311 (NC).

${ }^{61}$ ICICI Bank v Prakash Kaur (2007) 2 SCC 711.

${ }^{62} \mathrm{Goonda}$ is a colloquial term for goons or thugs.

${ }^{63}$ Vivek Mohan (Dr) v Canara Bank II (2007) CPJ 307 (NC).

${ }^{64}$ MI Plywood Industries v Canara Bank I (2013) CPJ 17 (NC).

${ }^{65} \mathrm{~A}$ constitutional bench of the Supreme Court refers to a bench with five judges. It considers questions of constitutional significance and is often unlikely to be overruled, given its higher bench strength.

${ }^{66}$ General Assurance Society Ltd v Chandumull Jain (1966) 3 SCR 500.
} 
It held that the court, through its interpretative process, could not rewrite or create a new contract between the parties. It must apply the terms and conditions as agreed. However, it did not go far enough to say that this would also be so in cases of ambiguity. In such cases, the terms are construed against the party who prepared the document. ${ }^{6}$ For example, in the case of an ambiguous Life Insurance Cover that was unclear on the meaning of a permanent disability, the National Commission broadened the term's definition against the insurance provider, who had drafted the cover, and benefited the assured. ${ }^{68}$

In 2004, the court again held that it could not take aid from outside the contract and read the terms strictly. ${ }^{69}$ In fact, it noted that there is no difference between a contract of insurance and any other contract and that both should be interpreted strictly without adding or deleting anything from the terms. ${ }^{70}$ As late as 2020, a bench of Justice Dr DY Chandrachud and Mr Ajay Rastogi observed that it could not rewrite the agreement between the parties and create a new contract to which the parties had not agreed. ${ }^{71}$ Although a contract must always be construed according to the parties' intention, that intention can only be ascertained from the instrument itself. All other evidence of intention is excluded because, when an agreement is reduced to writing, the parties are bound by the terms and conditions.

An important issue here is whether the consumers knew all the contract terms. If it is found that consumers knew about the terms, courts have enforced the terms of the contract, regardless of whether the terms themselves were unfair, one-sided, or opaque. On the other hand, if the terms were kept hidden from the consumer, courts have granted relief to consumers. Here, courts argue that an insurance contract is one of 'uberrima fides', ${ }^{2}$ and requires every material fact to be disclosed. When the insurance company dealt with the bank behind the insured's back, the National Commission held it to be a deficiency in service by the company. ${ }^{73}$ Similarly, when the insurance company only supplied the cover note and the insurance policy schedule, excluding other terms and conditions, the Supreme Court held

\footnotetext{
${ }^{67}$ United India Insurance Co v Pushpalaya Printers (2004) 3 SCC 694; Peacock Plywood (P) Ltd v Oriental Insurance Co (2006) 12 SCC 673; National Insurance Co v Ishar Das Madan Lal (2007) 4 SCC 105; and Mavji Kanji Jungi v Oriental Insurance Co 85 of 2014.

${ }^{68}$ Life Insurance Corporation of India v Ram Singh Tanwar I (2007) CPJ 48 (NC).

${ }^{69}$ United India Insurance Co v Harchand Rai Chandan Lal (2004) 8 SCC 644.

${ }^{70} \mathrm{M} / \mathrm{s}$ Industrial Promotion and Investment Corporation of Orissa Ltd v New India Assurance Co (2016) 15 SCC 315.

${ }^{71}$ Shree Ambica Medical Stores v The Surat People's Co-operative Bank Ltd 2020 SCC OnLine SC 92.

${ }^{72}$ Utmost good faith.

${ }^{73} \mathrm{M} / \mathrm{s}$ Taba Gloves Pvt Ltd v New India Assurance Co I (2010) CPJ 306 (NC).
} 
that the company could not take advantage of the excluded clauses since the consumer did not know about them. ${ }^{74}$

Another issue that arises in insurance contracts is knowledge during the settlement of claims. In addition to the time of entering into agreements, consumers should also have knowledge during settlement. Insurers are bound to ensure that no settlement is done with improper knowledge where the insured has no option but to accept the terms. The consumer's position becomes relevant to see whether she was unaware of any terms while signing the settlement. She may be able to satisfy the commission or court that the settlement had been obtained under misrepresentation or fraud. In such a case, a full and final settlement may be challenged. ${ }^{75}$ For example, a consumer agreed to receive only $4 \%$ of the total claim due to financial duress under the impression that the rest of the claim will be settled later. This settlement was set aside by the National Commission. ${ }^{76}$

Good faith forbids either party from concealing what she privately knows to draw the other into a bargain. Just as the insured must be cautious, the insurer must disclose all material facts to the consumer. If the insurer conceals a term while entering an agreement or during settlement, it cannot be used against the consumer. However, as seen, courts have not granted relief to consumers that cannot understand the terms. A consumer who has knowledge of the terms of a contract but cannot understand them faces the same challenges as if she was never made aware of the terms in the first place. This is especially concerning due to the growing financial inclusion in India. Many people are being introduced to complex products and contracts who do not have the wherewithal to understand them. At present, these consumers are unlikely to get their desired remedy if they approach a court.

\subsection{Caveat emptor}

The decision to hold a consumer responsible if she signed the documents is not unexpected. Courts are bound by the strict contractual enforcement precedent set as far back as $1934 .{ }^{77}$ Though courts have granted relief to parties that do not know contract terms, this is not the case consumers that do not understand the terms. This is because courts assume that parties understand the terms they sign. This may not be true. Since creditors cannot

\footnotetext{
${ }^{74}$ Modern Insulators Ltd $v$ Oriental Insurance Co (2000) 2 SCC 734.

${ }^{75}$ United India Insurance Co $v$ Ajmer Singh Cotton and General Mills (1999) 6 SCC 400 and National Insurance Co v Sehtia Shoes (2008) 5 SCC 400.

${ }^{76} \mathrm{M} / \mathrm{s}$ Inventa Chemicals Ltd $v$ United Insurance Co II (2004) CPJ 45 (NC).

${ }^{77}$ L'estrange v F Graucob ltd [1934] 2 KB 394. See also, Gautam Construction and Fisheries Ltd v National Bank of Agriculture and Rural Development (2000) 6 SCC 519.
} 
prevent informed consumers from doing business elsewhere, they have insufficient incentives to explain the economics of the market and the meaning of contract terms. ${ }^{78}$ Remuneration structures incentivise providers to push financial products regardless of how suitable they are for the consumer. ${ }^{79}$

Several new consumers have been introduced to complex products and contracts due to India's growing financial inclusion and have insufficient know-how. They are vulnerable to mis-selling. Sane and Halan (2017) have shown the importance of accessible and understandable disclosures so that consumers have a yardstick to measure firms and products. ${ }^{80}$ The strategy in Indian finance has historically focused on the doctrine of caveat emptor - let the buyer beware. Consumers were generally left to their own devices. At times, terms were disregarded if they defeated the entire contract or the creditor committed a fundamental breach. However, these are very high standards. Most parties cannot claim either of these as defences. They are not protected if they do not understand the contract terms, there was no negotiation about the contract, or there is a difference in the bargaining strength. Though the 2019 CPA gives consumer commissions the power to declare certain unfair terms as void, it does not address the ability to understand or negotiate the terms of the contract. ${ }^{81}$

This influences the decisions of consumers. It can be remedied by obligating firms to explain information that may be significant for consumers to make informed decisions. This should include disclosures to be made both before entering the agreement and any material changes after that. This can have significant consequences, especially in India, where financial literacy is low and regulatory enforcement appears weak. The 2019 CPA, through sector-specific rules, mandates e-commerce entities ${ }^{82}$ to make clear and understandable disclosures. It may be prudent to lay down similar sector-specific rules for finance disputes. Moreover, in 2018, a Bill was introduced in the Indian parliament, which addressed these challenges by acknowledging the role of understanding the terms, the bargaining strength of the parties, reasonable standards of fair dealing, and whether the terms were subject to any negotiation.

\footnotetext{
${ }^{78}$ Howard Beales, Richard Craswell, and Steven C Salop, "The efficient regulation of consumer information" (1981) 24(3) The Journal of Law and Economics 491.

${ }^{79}$ Roman Inderst and Marco Ottaviani, "Misselling through agents" (2009) 99(3) American Economic Review 883.

${ }^{80}$ Renuka Sane and Monika Halan, "Misled and mis-sold: Financial misbehaviour in retail banks?" (2017) 45(3) Journal of Comparative Economics 429.

${ }^{81}$ Unfair terms are restricted to excessive deposits for a contract's performance; disproportionate penalties on the consumer; refusal to accept early repayment of debts; unilateral termination; and unreasonable charges.

${ }^{82}$ Consumer Protection (E-Commerce) Rules 2020.
} 
However, the Bill has not passed parliament till now. ${ }^{83}$

Though courts have granted relief to unaware consumers, the role of knowledge should not be exaggerated. Disclosures appear to work only when they are about features consumers know and understand. For example, most people understand the concept of returns. Hence, they can digest it quickly. For disclosures to have any effect, consumers need to have a minimal understanding of the features that are being disclosed. ${ }^{84}$ Else, the same should be explained to them.

\section{Challenges in court functioning}

Our analysis suggests that though courts are often unable to grant relief to consumers. This may be due to several reasons - insufficient knowledge of finance cases, an absence of favourable procedure, etc. We turn next to understanding the shortcomings of courts as they deal with consumer finance disputes.

\subsection{Low compensation}

Compensation is a tool for granting adequate remedy. This includes a two-step process. The first is the disgorgement of unlawful profits from the offending party, which discourages future offences. ${ }^{85}$ The second is the return of what consumers lost through the wrongful act. As discussed in section 3.5, courts can mould reliefs case by case. Nonetheless, they tend to award low compensation that does not adequately compensate the complainant.

For example, in State Bank of India $v$ Rajender Lal, a cheque was dishonoured and lost in transit on its way back to the issuer. The bank did not inform her of this fact. The National Commission ruled out the liability of the collecting banker for the cheque. Still, it held him liable to pay compensation of ₹ 15,000 for the failure to inform the customer. ${ }^{86}$ This was the case even though the cheque was for ₹ 75,000. As per the Negotiable Instruments Act, ${ }^{87}$ the customer could have been liable to pay twice this amount and imprisoned for two years due

\footnotetext{
${ }^{83}$ Unfair (Procedural and Substantive) Terms of Contracts Bill 2018.

${ }^{84}$ Monika Halan and Renuka Sane, "Regulating consumer finance: Do disclosures matter? The case of life insurance" [2017] NIPFP Working Paper No 212.

${ }^{85}$ Lon Luvois Fuller and William R Perdue, "The reliance interest in contract damages: 1" (1936) 46(1) The Yale Law Journal 52; and George P Roach, "A Default Rule of Omnipotence: Implied Jurisdiction and Exaggerated Remedies in Equity for Federal Agencies" (2007) 12 Fordham J Corp \& Fin L 1.

${ }^{86}$ State Bank of India v Rajender Lal IV (2003) CPJ 53 (NC).

${ }^{87}$ Negotiable Instruments Act 1881, s 138.
} 
to the bank's fault. In another case, the customer was awarded a meagre compensation of ₹ 500 for dishonouring a draft without justification. ${ }^{88}$

The problem of low compensation is known to consumer courts. In SK Bhatia v Punjab National Bank, the State Commission acknowledged that the District Commission's award was "too meagre". In this case, the bank delayed returning the security of the customer for 14 years. The security included jewellery totalling 304 grams of gold. Though the gold's quality is unknown, the price of 24 karat gold when the security was due (1982) was approximately ₹ 1,645 for ten grams. This meant that the complainant had been deprived of the use of close to $₹ 50,000$ at the time. This would have garnered interest over the 14 years. However, the State Commission only increased the meagre compensation of ₹ 1,000 of the District Commission to ₹ $5,000 .^{89}$

The challenge of low compensation was probably at the forefront in 2014. Here, the Allahabad High Court granted an award without interest for the seven years that it should have been payable. In Dr Virendra Pal Kapoor v Union of India, a senior citizen had invested ₹ 50,000 in a unit-linked product in 2007. Upon payout in 2012, he had lost the entire sum except for ₹ 248 on account of hidden charges. He had been mis-sold a higher-risk policy without any caution. The High Court declared the policy to be illegal and void. The issuer was directed to return the original amount of ₹ 50,000 and pay costs of ₹ $10,000 .{ }^{90}$ However, no interest was ordered. Though it appears that the complainant had not separately requested interest, nothing barred the High Court from granting the same.

\subsection{Delay}

Low compensation and low interest rates become more severe when it takes long for disputes to be settled. The CPA provides that an endeavour shall be made to decide complaints within three months unless testing or analysis is required, in which case a decision should be reached within five months. Similarly, appeals must be decided within three months. Section 4.1 shows that it takes 1.99 years to settle a banking dispute before the National Commission. This is 2.38 years for insurance disputes. These are more than five times the statutory guideline of five months. $65 \%$ of banking and $71 \%$ of insurance cases do not meet the three- or five-month goals. In fact, it took over 5 years to decide more than $1 / 5$ th of the cases. As per the National Judicial Data Grid, the average time for a pending civil case in

\footnotetext{
${ }^{88}$ Vasudev Bhai $v$ Bank of Baroda (1993) 2 CPR 421 (Guj).

${ }^{89}$ SK Bhatia v Punjab National Bank III (1996) CPJ 375 (HP).

${ }^{90}$ Dr Virendra Pal Kapoor v Union of India 2014 SCC OnLine All 15648.
} 
India was 3.49 years as of July $13^{\text {th }} 2020,{ }^{91}$ slightly more than the gestation period before the National Commission. This may be due to several reasons, such as the difference in procedural requirements before the commission and ordinary courts.

However, the benchmark of an average civil case may not be too high. It reflects the time taken before a district court. In contrast, the National Commission is an appellate body, and the questions that it needs to answer are limited. It is thus expected to dispose matters as quickly as possible. It may be the second, if not the third, stage of litigation since a lower forum could have earlier heard the same case. Hence, the time taken by the commission is in addition to that which has already been spent on the litigation. This reflects the delay in settlement of disputes by the commission.

Consumer courts have attempted to make sure that insurers provide speedy settlement. They are not ignorant of the delay caused at that end. For example, where the amount worked out by the surveyor was accepted by the complainant, yet the payment was not made for several years, the commission awarded $18 \%$ interest and ₹ 5,000 compensation. ${ }^{92}$ It has held that providers should settle insurance claims within six months. Otherwise, it causes considerable loss and mental agony to the insured. ${ }^{93}$ However, courts do not seem to apply this standard to themselves. The average time to decide a case has been on the rise. It took 1.66 years for an insurance dispute to be resolved in 2009. Ten years later, this was 2.38 years in 2019 . Approximately four times as many cases are initiated each year as are decided. This leads to a rising backlog of cases, which will only slow adjudication time in the future. For example, in February 2020, the National Commission adjourned a matter till January 2021 - almost a year after the hearing. ${ }^{94}$

This is a cause for concern. A judicial proceeding is a tripartite process involving two litigants and a judge. If there are incentives for any party to cause delay, it is natural to expect it to do so. ${ }^{95}$ In finance and credit cases, a delay is likely to help banks use the

\footnotetext{
${ }^{91}$ National Judicial Data Grid, "Summary Report of India as on July 13th 2020" $\langle$ https://njdg.ecourts. gov.in/njdgnew/index.php $\rangle$.

${ }^{92}$ Ishwarbhai Lallubhai Patel v New India Assurance Co 19932 CPR 440 Guj. See also, Prem Prakash Mehra $v$ Oriental Insurance Co (1995) 3 CPR 407 Punjab.

${ }^{93}$ Oriental Insurance Co v Malati Paul II (1996) CPJ 109 (NC) In this case, the claim arose in 1986, and the surveyor report was concluded in 1987. However, the insurer failed to settle the claim till 1992.

${ }^{94}$ Murali Krishnan, Supreme court urges consumer forum to look into grievance of yearlong adjournment (Hindustan Times 16 August 2020) 〈https://www.hindustantimes.com/india-news/supreme- court- urgesconsumer- forum- to- look- into- grievance- of- year- long- adjournments / story-eIouknROhojIcV0b1XB7TO . html $\rangle$.

${ }^{95} \mathrm{~A}$ study of debt recovery tribunals found that plaintiffs were the leading cause of delay (Prasanth Regy
} 
deposits that consumers may have made. This is especially when they may cause delays via several claims, such as lost documents and the need for translations. This has adverse consequences. If creditors know that they can delay penalisation, if not stop it, they will be more likely to default. These delays may be compounded by a lack of proper infrastructure and constant vacancies at consumer courts. ${ }^{96}$ Chemin (2012) studied the effect of procedural law changes on the economy. He found that speeding up court processes led to a decrease in the likelihood of breach of contract and increased investment and access to credit markets. ${ }^{97}$

\subsection{No class action}

If consumers cannot understand complex financial agreements, they may benefit from pooling their knowledge and approaching courts as a class. Plaintiffs can share resources such as evidence, expert witnesses, and litigation costs. ${ }^{98}$ However, unlike other countries, such suits are few and far between in India. The absence of class action suits may be because of unclear substantive law. This makes it difficult for class members to come together. For example, the National Commission has said that it would not permit a case if only 10 persons out of a class of 100 wish to litigate. ${ }^{99}$ This standard can be difficult where the class is likely to be millions of consumers. While 10 out of 100 injured parties may seem inadequate, if 100,000 out of a million customers of a bank form a class, it may be hard to argue that the class is inadequate.

Moreover, the 2019 CPA establishes a new regulator in the regime of consumer protection i.e. the CCPA. Now, a complaint relating to violations of consumer rights prejudicial to a class's interest is to be forwarded to the CCPA. ${ }^{100}$ It then conducts a preliminary inquiry about whether there exists a prima facie case and conducts an investigation. This has taken away the power to initiate class actions from individuals and vested them into the regulator's hands. Persons who have suffered harm are now supplicants before the regulator, requesting it to enforce consumer law. Several steps have been added in the process, which may lead and Shubho Roy, "Understanding Judicial Delays in Debt Tribunals" [2017] NIPFP Working Paper No 195). See also Pratik Datta, BS Surya Prakash, and Renuka Sane, "Understanding Judicial Delays at the Income Tax Appellate Tribunal in India" [2017] NIPFP Working Paper No 208.

${ }^{96}$ State of UP v All UP Consumer Protection Bar Association (2017) 1 SCC 444.

${ }^{97}$ Matthieu Chemin, "Does court speed shape economic activity? Evidence from a court reform in India" (2012) 28(3) The Journal of Law, Economics, \& Organization 460.

${ }^{98}$ Brian T Fitzpatrick, "Do Class Action Lawyers Make Too Little?" (2010) 158(7) University of Pennsylvania Law Review 2043.

${ }^{99}$ Ambrish Kumar Shukla and 21 Ors v Ferrous Infrastructure Pvt Ltd I (2017) CPJ 1 (NC).

${ }^{100}$ It is unclear whether a class action will directly be allowed before a consumer court. Specific provisions for a class remedy by the CCPA may imply that courts will require parties to first approach the regulator. 
to a lesser filing of class action suits.

Solving these issues will not lead to class actions. This is because of the incapacity of people to finance such disputes. Litigation is expensive. Legal systems usually allow these expenses to be borne by third-parties. If members win, they share the proceeds with the third party. In 2018, the Supreme Court observed that there is no limitation on third-party funding (TPF). ${ }^{101}$ However, there is no central law on TPF in India. Courts have left it to their discretion whether financing agreements are just and fair. In the absence of statutory requirements, courts usually lay down legal tests. This allows parties to predict the behaviour of the courts and make appropriate arrangements. However, there are no tests to determine the appropriateness of TPF agreements. Their validity is entirely up to a judge's concept of just-ness, leading to an unevolved TPF market in India.

Lastly, India also prohibits contingency fees. ${ }^{102}$ This is the fees paid to lawyers as a stake in the outcome. Lawyers may have an incentive to engage in self-dealing. ${ }^{103}$ This is especially so in class actions where class members may not be able to act as good monitors of the lawyers, and client cohesion is unusual. Contingency fees solve this problem by linking the lawyer's fees to the benefit she provides. Moreover, TPFs usually seek contingency fees of legal counsel, as this ensures the alignment of interests. Thus, the lack of contingency fees also harms TPF. The laws in India create a system that either prohibits or disincentives class actions. ${ }^{104}$

\subsection{Specialisation}

In markets where consumers cannot understand financial agreements or share resources, courts should fill the knowledge gap. However, consumer courts in India have been created to resolve all consumer disputes. Though the members are highly qualified individuals, they lack specialisation in finance disputes. In June 2020, the National Commission included retired judges, bureaucrats, and a medical negligence professor. ${ }^{105}$ None of whom have a

${ }^{101}$ Bar Council of India v AK Balaji (2018) 5 SCC 379. See also, Ram Coomar Coondoo v Chunder Canto Mookerjee 1876 SCC OnLine PC 19.

${ }^{102}$ Standards of Professional Conduct and Etiquette to be Observed by Advocates 1975.

${ }^{103}$ Alexandra Lahav, "Fundamental Principles for Class Action Governance" (2003) 37 Ind L Rev 65.

${ }^{104}$ Karan Gulati and Renuka Sane, Why do we not see class-action suits in India? The case of consumer finance, "Leap Blog" (3 May 2020) 〈https://blog.theleapjournal.org/2020/05/why-do-we-not-see-classaction-suits-in.html $\rangle$.

${ }^{105}$ The commission has eight members. The judicial members are: Justice RK Agrawal (president), Justice VK Jain, and Justice Deepa Sharma. The non-judicial members are: Mr Prem Narain, Mr AK Thakur, Dr SM Kantikar, and Mr Dinesh Singh. 
background in finance. This is compounded by the fact that consumer disputes cannot be arbitrated, where parties could appoint experts in the field. The position in India is unlike other common law countries where sectoral experts adjudicate finance disputes.

Unlike India, other countries have had a long history of dealing with consumer finance and credit cases. This has resulted in a framework that targets individual grievances with specialised mechanisms instead of relying on a general consumer protection law. For example, in UK, the credit systems for secure and unsecured lending are set out in the Consumer Credit Act $(\mathrm{CCA})^{106}$ and the Financial Services and Markets Act (FSMA). ${ }^{107}$ Failure to act as per the requirements can affect agreements and result in legal action. This is supplemented by prerequisites of fairness under the Consumer Rights Act (CRA). ${ }^{108}$ Grievance redress has not followed a common trajectory in different countries. However, they have adopted extensive adjudicatory legislation regarding financial products and services, leading to a specialised body of knowledge. On the other hand, laws in India regarding finance have been restricted, leaving courts to start from a clean slate. Assuming that timeliness and predictability can make India's finance regime more appealing to creditors and debtors, specialisation by adjudicators could prove valuable.

\section{Way forward}

Grievance redress by courts, in its current form, faces several challenges. One obvious way to improve the system is by general improvements in the judiciary's capacity and knowledge. However, such an ambitious undertaking may be an unreasonable near-term goal. If so, policymakers might consider adopting certain targeted interventions. Table 2 gives some such interventions and the implementation authorities for the same.

There are two kinds of interventions that are required. First is on the legislative front, where better laws are drafted. Most of the challenges outlined in sections 4 and 5 can be addressed by amendments in the CPA 2019 or rules made under the Act. Like the targeted legislation in other countries and sector-specific requirements in India, the legislature could enact separate rules for financial transactions. For example, it could mandate clear and understandable disclosures by FSPs. This could be supplemented with requirements to explain the disclosures to consumers. Another option would be to pass the Unfair (Procedural and Substantive) Terms of Contracts Bill. Since unfair terms may be a challenge in non-

\footnotetext{
${ }^{106}$ Consumer Credit Act 1974.

${ }^{107}$ Financial Services and Markets Act 2000.

${ }^{108}$ Consumer Rights Act 2015.
} 
consumer finance disputes, such a solution would address the issue in all civil cases.

Policymakers may also consider prescribing adequacy requirements in class action suits and transitioning towards contingency fees for lawyers and third-party investors. ${ }^{109}$ This would enable consumers to come together as a class and seek redress for the grievances that would go unaddressed if they had to individually approach the court. Moreover, they could adopt a separate set of tribunals for finance cases, perhaps making much of the processes administrative in nature. This would require a comprehensive study of India's history with tribunalisation to not repeat any difficulties faced in the past. One way would be to constitute an advisory council on consumer finance. ${ }^{110}$ The advisory council may be responsible for making representations about policies; reviewing, monitoring, and reporting their effectiveness; and highlighting its views on new rules and regulations. Ideally, it would consist of consumers or persons representing their interests. The appointment of members of the council should also give a fair degree of representation to experts in personal finance and consumer rights.

Second, are interventions on the judicial process. For example, one of the problems we identify is low compensation. This may be because there are no guidelines for courts to follow while awarding the same. Though the 2019 Act now prescribes high maximum penalties, this only gives a wide range to the judges. There is no expert analysis of the loss nor any standards to be followed. In the absence of financially prudent legislation, courts often tend to award compensation that only makes sense when the legislation is enacted. ${ }^{111}$ This soon loses its relation with market rates. One way to address this is to update and consolidate rules governing compensation considering modern market understanding. Other jurisdictions often order disgorgement (surrender of profits earned through illegal means) or grant a remedy of restitution. ${ }^{112}$ This seeks to measure actual damages based on the defendant's ill-gotten gains and the plaintiff's loss based on their capital cost and the opportunity cost of money.

Similarly, a lot has been said about judicial delay in India. Though the government has made several attempts to address delay, the judiciary may be better suited to remedy the situation. In particular, the Supreme Court has laid down guidelines for tribunals' functioning as

\footnotetext{
${ }^{109}$ The latter would need amendment in rules made by the Bar Council of India.

${ }^{110}$ Financial Sector Legislative Reforms Commission, "Report of the financial sector legislative reforms commission, Vol I, New Delhi" [2013].

${ }^{111}$ Karan Gulati and Shubho Roy, India's low interest rate regime in litigation, "Leap Blog" (11 March 2020) 〈https://blog.theleapjournal.org/2020/03/indias-low-interest-rate-regime-in.html〉.

${ }^{112}$ Caprice L Roberts, "Restitutionary Disgorgement for Opportunistic Breach of Contract and Mitigation of Damages" (2008) 42 Loy LAL Rev 131.
} 
recently as 2019. ${ }^{113}$ One way to address delays is for the National Commission to exercise its power to call for statistics regarding the institution, disposal, and pendency of cases in the State Commissions and conduct systematic reviews. This would enable a deeper understanding of the causes for delay and deployment of forum specific solutions. Courts can also choose to prioritise older disputes which have been pending for too long. Classification as old cases may seem subjective; however, one way would be to hear disputes pending for longer than the legislative mandate or a multiple of that period. Another way for commissions to handle incoming cases may be to separate their judicial and administrative functions. ${ }^{114}$ This proposal is not novel, and creating a 'National Judicial Centre' was suggested by the Law Commission of India (LCI) as far back as 1988. ${ }^{115}$ This is likely to reduce the time it takes to conclude hearings since members of the commission would have more time to focus on their judicial tasks.

These solutions can have significant consequences, especially in India, where financial literacy is low and regulatory enforcement appears weak. Though they were developed after studying consumer finance disputes, they may have consequences outside this domain and yield better functioning courts. Market-oriented compensation, without delay, when parties can come together as a class would be beneficial in any dispute.

\footnotetext{
${ }^{113}$ Rojer Mathew v South Indian Bank Ltd 2019 SCC OnLine SC 1456. In L Chandra Kumar v Union of India (1997) 3 SCC 261, the Supreme Court observed that:

one reason why these Tribunals have been functioning inefficiently is that there is no authority charged with supervising and fulfilling their administrative requirements...The creation of a single umbrella organisation will, in our view, remove many of the ills of the present system.

See also, Union of India $v$ R Gandhi (2010) 11 SCC 1 and Madras Bar Association v Union of India 2019 SCC OnLine SC 424.

${ }^{114}$ Pratik Datta, Mehtab Hans, Mayank Mishra, and others, "How to Modernise the Working of Courts and Tribunals in India" [2019] NIPFP Working Paper No 258.

${ }^{115}$ Law Commission of India, The Supreme Court - A Fresh Look (Report No 125, 1988).
} 


\begin{tabular}{ll}
\hline \multicolumn{1}{c}{ Actionable Task } & \multicolumn{1}{c}{ Reason } \\
\hline $\begin{array}{l}\text { Obligate firms to explain information to } \\
\text { consumers. }\end{array}$ & $\begin{array}{l}\text { A consumer who has knowledge of the terms but cannot } \\
\text { understand them faces the same challenges as if she was } \\
\text { never made aware of the terms in the first place. This } \\
\text { places FSPs at an unfair advantage. }\end{array}$ \\
\hline $\begin{array}{l}\text { Update the rules governing compensation } \\
\text { by linking it to market rates and loss }\end{array}$ & $\begin{array}{l}\text { There are no guidelines for courts to follow while awarding } \\
\text { compensation nor any expert analysis of the loss. This has } \\
\text { to the parties. }\end{array}$ \\
\hline
\end{tabular}

Call for statistics and conduct systematic

reviews.

Prioritise disposal of old disputes.

Separate judicial and administrative functions.

Prescribe adequacy requirements in class action suits.

Transition towards contingency fees and third-party investors.
Delays in consumer courts have adverse consequences. If creditors know that they can delay penalisation, they will be more likely to default. Speeding up court processes may lead to a decrease in the breach of contracts since parties will factor in timely penalisation by courts.

Judiciary

Judiciary

Judiciary

In class actions, plaintiffs can share resources such as evidence, expert witnesses, and litigation costs. They may

Legislature be able to seek redress for the grievances that would have gone unaddressed if plaintiffs had to approach the court individually.

Bar Council of India

Constitute an advisory council on consumer Consumer courts were created to resolve all consumer finance. disputes. They lack specialisation in finance disputes. 


\section{Conclusion}

This paper studies the role of courts in consumer finance disputes in India. We find that in banking disputes, courts have generally granted relief to consumers in banking disputes, but only when the complaint was filed without delay. In insurance, courts have emphasised contractual compliance. Hence, consumers did not get a remedy in cases where the contracts had unfair or complex terms. Courts also tend to award low compensation, take a long time for adjudication, do not have systems for class action suits, and lack specialisation to deal with consumer finance issues.

This paper is one of the first to study the role of courts in consumer finance redress issues. Our analysis points to the difficulties in approaching courts for redress. The problem is made worse due to the information asymmetry between consumers and FSPs. In a growing financial landscape such as India, where consumers have less knowledge about options in financial contracts, issues in redress bodies such as the judiciary can be exacerbated. Here, breakdowns in consumer protection imply high costs both to individual consumers and the market as a whole. 


\section{MORE IN THE SERIES}

Rao, R Kavita., (202I). The Economy as Reflected in Income Tax Data, WP No. 330 (March).

Damle, D., (202I). Dam Safety in India, WP No. 329 (March).

Chakraborty, L., (202I).

Macroeconomic Framework of Union Budget 202I-22:

Reconsidering the Fiscal Rules, WP No. 328 (March).
Karan Gulati, is Research Fellow, NIPFP

Email: karan.gulati@nipfp.org.in

Renuka Sane, is Associate Professor, NIPFP Email: renuka.sane@nipfp.org.in

National Institute of Public Finance and Policy, 18/2, Satsang Vihar Marg,

Special Institutional Area (Near JNU),

New Delhi 110067

Tel. No. 26569303, 26569780, 26569784

Fax: 91-11-26852548

www.nipfp.org.in 